\title{
Donations Made and Received: A Study of Disclosure Practices of Pharmaceutical Companies and Patient Groups in Canada
}

\author{
Joel Lexchin ${ }^{1,2,3 *} \mathbb{0}$
}

\begin{abstract}
Given the increasing role of patient groups in pharmaceutical policy-making in Canada, this observational study was undertaken to determine whether companies that are members of Innovative Medicines Canada (IMC) list, on their publicly available websites, the names of patient groups that they make donations to and reciprocally, whether patient groups publicly list the names of the companies that they receive donations from. Websites of IMC members were searched for the names of the patient groups receiving donations, value of the donations and year the donations were made. The website of each patient group that was listed as receiving a donation was then searched for information about the name of companies making donations along with the value of the donations, year the donations were made and percent of the patient groups' income represented by the donation. For donations over $\$ 50000$, an attempt was made to match donations that companies made to donations that patient groups received. Eleven of 44 IMC members reported making 165 donations to 114 different patient groups. Seventy-nine of these 114 groups reported receiving 373 donations from IMC members. Information about the value of donations, the year that they were given and received and the percent of patient groups' income that they represented was limited. Donations made and received could not be matched because of the absence of information about the donations. Reporting on websites about donations by both companies and patient groups in Canada is haphazard, inconsistent and incomplete. Reforms are need to both the way that companies and patient groups report donations.

Keywords: Canada, Donations, Patient Groups, Pharmaceutical Companies, Reporting

Copyright: @ 2022 The Author(s); Published by Kerman University of Medical Sciences. This is an open-access article distributed under the terms of the Creative Commons Attribution License (https://creativecommons.org/licenses/ by/4.0), which permits unrestricted use, distribution, and reproduction in any medium, provided the original work is properly cited.

Citation: Lexchin J. Donations made and received: a study of disclosure practices of pharmaceutical companies and patient groups in Canada. Int J Health Policy Manag. 2022;11(10):2045-2053. doi:10.34172/ijhpm.2021.172
\end{abstract}

\section{Article History:}

Received: 31 May 2021

Accepted: 13 December 2021

ePublished: 14 December 2021

*Correspondence to:
Joel Lexchin
Email: jlexchin@yorku.ca

\section{Introduction}

Understanding financial relationships between patient groups and pharmaceutical companies is a necessary component of evaluating the position that patient groups take when the interests of companies are involved. One example of where patient groups may be favouring the companies that are donating to them is with respect to the submissions that they make to the Common Drug Review (CDR) and the panCanadian Oncology Drug Review (pCODR), both arms of the Canadian Agency for Drugs and Technology in Health. CDR and pCODR conduct health technology assessments and make recommendations to public drug plans (except the one in Quebec) about whether the provincial drug plans should fund medications for particular indications. When patient groups make submissions, they need to declare any financial conflicts of interest (ie, grants, donations and other transfers of value) they have with pharmaceutical companies and these conflicts are made publicly available. Up until July 22, 2018, 93 patient groups made 372 submissions and declared conflicts in $324(87 \%)$ of them and the groups supported funding in over $90 \%$ of their submissions. ${ }^{1}$
Internationally, reporting of donations by large companies is variable ${ }^{2}$ but this issue has not been investigated in the Canadian context. Since 2009, the Code of Ethical Practices from Innovative Medicines Canada (IMC), the lobby group representing brand-name manufacturers, has included a voluntary guideline for its membership stating that they should "disclose, by means of their web sites and annual reports, a list of all stakeholders to which they provide direct funding." ${ }^{3}$ However, there are no penalties for not disclosing and no evaluation has been undertaken to determine if companies are voluntarily complying with this provision. There are also no voluntary or mandatory requirements for companies that are not IMC members to report donations (IMC members are the largest component of the researchbased industry in Canada, accounting for $73 \%$ of the dollar sales of patented medicines ${ }^{4}$ ).

In Canada, it is difficult to obtain information on funding of patient groups by pharmaceutical companies aside from what is revealed in submissions to CDR and pCODR. Most patient groups are registered charities and file annual financial reports to the Canada Revenue Agency, but those publicly 
available reports do not contain information about individual donations. See, for example, the financial report for Canadian Cancer Survivor Network at https://apps.cra-arc.gc.ca/ebci/ hacc/srch/pub/dsplyRprtngPrd?q.srchNm=canadian+canc er+survivor+network\&q.stts $=0007 \&$ selectedCharityBn $=8$ $34540882 \mathrm{RR} 0001 \& \mathrm{dsrdPg}=1$. The question about whether patient groups voluntarily reveal the names of pharmaceutical company donors and information about the donations on their websites has not been investigated.

This study was undertaken to determine whether companies that are members of IMC list on their publicly available websites the names of patient groups that they make donations to and what other information about the donations is provided. A similar search of the websites of the named patient groups was done to see if they publicly list the names of the companies that they receive donations from and what other information they provide about the donations. The study also investigates the extent of congruency between company and patient group disclosures of donations made and received.

\section{Methods}

Source of Data About Donations

The websites of all 44 IMC members ${ }^{5}$ were manually searched between March 24-26, 2021 to determine if the company listed patient groups that it made donations to. If the manual search was unsuccessful, then a Google search of the website was done using the terms "donation," "grant," "patient group" and "sponsor." If names of patient groups were found, then the name of each patient group was entered into an Excel spreadsheet along with the URL for the company webpage containing the names, the pathway and number of mouse clicks from the website home page to the page containing the information about donations, the year donations were made, the value of donations in dollars and the purpose of donations. When it was unclear if different names referred to the same patient group, a Google search was done on all the names. If the search returned the same URL for each name, then the conclusion was reached that it was a single group. If a company made a donation to multiple branches of the same organization each donation was treated separately, eg, donations by a single company to Lung Association Canada, Lung Association - British Columbia and Lung Association Manitoba were treated as three separate donations. If a single company made multiple donations to one group in the same year, it was treated as a single donation.

Patient groups were defined as those whose primary mission is to combat a particular disease or disability or to work toward improving the health and well-being of a particular patient population. ${ }^{6}$ In-line with the definition of a patient group, donations to other organizations, for example, foundations whose primary focus was on fund raising for a particular disease, coalitions of patient groups focusing on diverse diseases or to non-Canadian groups were not included. International groups with a branch in Canada were only considered if it was clear that the Canadian branch received funding directly from one or more pharmaceutical companies and made independent decisions about how the donations were spent. (No organization met this definition). The website of each patient group that was listed as receiving a donation was then manually searched, also between March 24-26, 2021, to determine if the group disclosed the names of the donor companies and other information about the donation. If the manual search was unsuccessful, then a Google search of the website was done using the name(s) of one or more companies that declared making a donation to the group. If the names of companies were found, then the following data were collected and entered into an Excel spreadsheet: name(s) of IMC member companies making the donations, URL for the webpage containing the names, pathway and number of mouse clicks from the website home page to page containing the information about the donation, year the donations were received, value of the donations in dollars, purpose of the donations and percent of group's income represented by the donations. If patient groups listed the names of donors and information about donations in multiple places on their websites, eg, in their annual reports and elsewhere on their websites, then the most comprehensive information was used. Donations to a single group from a parent company and one of its subsidiaries were treated as coming from different companies if the parent and subsidiary were both members of IMC. In addition, donations to patient groups from non-IMC members were recorded.

All dollar amounts are reported in Canadian dollars.

Patient groups and companies were not directly contacted as the study aim was to assess the completeness of available information on donations on public websites.

\section{Analysis}

Counts were done of the number of companies that reported making donations, the number of donations per company and whether the following information was available: year of the donation, value of donation and purpose of the donation. The same information was summed for donations that patient groups reported receiving, plus information about the percent of the group's income represented by donations from companies. Only descriptive data is reported. This study followed the Strengthening the Reporting of Observational Studies in Epidemiology (STROBE) reporting guideline for cross-sectional studies. ${ }^{7}$

\section{Ethics and Data Availability}

Since all information was publicly available ethics approval was not required. The datasets collected and analyzed during the current study are available from the corresponding author on reasonable request.

\section{Results}

Reporting of Donations by Companies

Eleven of the 44 members of IMC reported on their websites making 165 donations to 114 patient groups (Table 1). (Supplementary file 1 lists companies not reporting making donations). Individual companies made donations to between 1 and 46 different patient groups. The median number of companies reporting donations to a single group was 1 (interquartile range [IQR] 1,2), but in one case 5 companies 
Table 1. Innovative Medicines Canada Member Companies Reporting Making Donations to Patient Groups

\begin{tabular}{|c|c|c|c|c|c|}
\hline $\begin{array}{l}\text { Name of } \\
\text { Company }\end{array}$ & $\begin{array}{l}\text { No. of Patient Groups } \\
\text { That Received } \\
\text { Donations }\end{array}$ & $\begin{array}{l}\text { Year } \\
\text { Donations } \\
\text { Made }\end{array}$ & $\begin{array}{l}\text { Amount of } \\
\text { Donation }\end{array}$ & $\begin{array}{l}\text { Purpose of } \\
\text { Donation }\end{array}$ & $\begin{array}{l}\text { Pathway From Home Page of Company to List of Patient } \\
\text { Groups Receiving Donations (No. of Mouse Clicks) }\end{array}$ \\
\hline AbbVie & 45 & Not stated & Not stated & Not stated & Community: Patient Associations (2) \\
\hline Bayer & 16 & 2020 & $\begin{array}{l}\text { Greater than } \\
\$ 5000\end{array}$ & Not stated & $\begin{array}{l}\text { This is Bayer: Our Business Areas: Pharmaceuticals: Grants } \\
\text { and Sponsorships (4) }\end{array}$ \\
\hline GlaxoSmithKline & 16 & 2020 & Exact amount & Yes & $\begin{array}{l}\text { Responsibility: Responsibility reports and additional data: } \\
\text { Patient group funding (3) }\end{array}$ \\
\hline Roche & 24 & 2019 & Exact amount & Yes & $\begin{array}{l}\text { Menu: About Roche: Ethics and integrity: Patient organization } \\
\text { grants and donations (leaving Roche Canada website): } \\
\text { Working with patient organizations (4) }\end{array}$ \\
\hline Leo & 3 & Not stated & Not stated & Not stated & About us: Corporate social responsibility (2) \\
\hline Novartis & 46 & 2019 & Exact amount & Yes & $\begin{array}{l}\text { About us: Corporate responsibility: The Novartis commitment } \\
\text { to patients and caregivers: Patient community (leaving } \\
\text { Novartis.ca website): Our company: Corporate responsibility: } \\
\text { Corporate responsibility reporting and disclosure: } \\
\text { Transparency and disclosure: Patient organization funding: } \\
\text { Download the } 2019 \text { report (10) }\end{array}$ \\
\hline Novo Nordisk & 7 & Not stated & Not stated & Not stated & About us: In the community (2) \\
\hline Paladin & 1 & 2020 & Not stated & Yes & Community (1) \\
\hline Pfizer & 1 & 2018 & Exact amount & Yes & $\begin{array}{l}\text { Media centre: Pfizer Canada announces support to Heart \& } \\
\text { Stroke's \#timetoseered campaign ( } 2 \text { ) }\end{array}$ \\
\hline Purdue & 3 & 2018 & Not stated & Not stated & $\begin{array}{l}\text { Corporate social responsibility: Sponsors, donations and } \\
\text { grants: Grant recipients: Grant recipient list } 2018 \text { (4) }\end{array}$ \\
\hline Takeda & 3 & Not stated & Not stated & Not stated & Who we are: Our partnerships (2) \\
\hline
\end{tabular}

reported donating to a single patient group. Six companies stated the year the donation was made - one said 2018, two said 2019 and the other three said 2020. Six companies (AbbVie, Leo, Novo Nordisk, Paladin, Purdue, Takeda) did not disclose the dollar amount of any of the donations that they made. Bayer stated that all donations were for greater than $\$ 5000$. Paladin disclosed the purpose of the single donation listed on its website. Pfizer disclosed the amount and purpose of the single donation that was reported on its website, while Roche, GlaxoSmithKline and Novartis did the same for their multiple donations.

\section{Placement of Information About Donations on Company} Websites

Donations were listed in multiple places on companies' websites and it took a median of 2 mouse clicks (IQR 2, 4) to find the information. For Paladin it took only a single mouse click from the home page to access the information about the donation, whereas for Roche and Novartis it required leaving their Canadian webpages and reaching the information for Novartis took 10 mouse clicks (Table 1).

\section{Reporting of Donations by Patient Groups}

Seventy-nine of 114 (69.3\%) patient groups reported receiving a total of 373 donations (median number 4, IQR 2, 7) (Table 2 and Supplementary file 2), including from 19 of the 33 IMC members that did not report making donations on their websites. Thirty-five out of 114 patient groups (30.7\%) that companies reported making donations to did not acknowledge receipt of donations from that company. (Supplementary file 3 lists the patient groups not reporting receiving a donation from IMC member companies). Eighteen of the 79 groups that reported receiving donations did not list all the companies that claimed that they donated to the groups. Janssen and Merck did not report making any donations and Pfizer only reported a single donation. Summing the number of patient groups that reported receiving donations from one or more of these three companies, each of the companies made donations to more than 25 different groups that they did not report.

Twenty patient groups $(25.3 \%$ of all groups reporting any donations) stated the year when they received the donations; aside from two groups that reported receiving donations in 2017, all the other groups said the donations were received in 2019 or after (Table 2 and Supplementary file 2). Fourteen groups $(17.7 \%)$ reported the dollar range of the donations (eg, \$5000-\$10000), 8 groups (10.1\%) put donations into categories (eg, gold, silver, bronze) without giving a dollar value for the categories and the remaining 57 groups (72.2\%) did not report the value of the donations. Four groups provided information about the purpose of donations, but none of the 79 groups that received donations said the proportion of their overall income represented by the donations or gave information that would allow this calculation. Eight patient groups also reported receiving donations from IMC itself. The IMC website did not report any of these donations. Finally, 47 patient groups reported the receipt of 95 donations ( 1 to 11 donations per group) from 56 non-IMC member companies.

Placement of Information About Donations on Patient Group Websites

Locating information about the donations required a median of 2 mouse clicks (IQR 1,2). Fourteen groups listed the names 
Table 2. Information About Donations Reported by Patient Groups

\begin{tabular}{|c|c|c|c|c|c|c|c|c|}
\hline \multirow{2}{*}{$\begin{array}{l}\text { No. of Patient } \\
\text { Groups } \\
\text { Reporting } \\
\text { Receiving } \\
\text { Donations }\end{array}$} & \multirow{2}{*}{$\begin{array}{l}\text { Median Number } \\
\text { of Donations } \\
\text { Received Per } \\
\text { Group (IQR) }\end{array}$} & \multirow{2}{*}{$\begin{array}{l}\text { No. of Groups } \\
\text { Reporting } \\
\text { Year Donation } \\
\text { Received } \\
\text { (Percent of } \\
\text { Total) }\end{array}$} & \multicolumn{3}{|c|}{$\begin{array}{c}\text { No. of Groups Reporting Value of } \\
\text { Donations }\end{array}$} & \multirow{2}{*}{$\begin{array}{l}\text { No. of Groups } \\
\text { Reporting Percent } \\
\text { of Overall Income } \\
\text { From Donations } \\
\text { (Percent of Total) }\end{array}$} & \multirow{2}{*}{$\begin{array}{c}\text { No. of } \\
\text { Group } \\
\text { Reporting } \\
\text { Purpose of } \\
\text { Donations } \\
\text { (Percent of } \\
\text { Total) }\end{array}$} & \multirow{2}{*}{$\begin{array}{l}\text { Median No. of } \\
\text { Mouse Clicks to } \\
\text { Find Information } \\
\text { About Donation } \\
\text { (IQR) }\end{array}$} \\
\hline & & & $\begin{array}{l}\text { Dollar } \\
\text { Range }\end{array}$ & Category $^{\mathrm{a}}$ & $\begin{array}{c}\text { No } \\
\text { Information }\end{array}$ & & & \\
\hline 79 & $4.0(2.0,7.0)$ & $20(25.3)$ & 14 (17.7) & $8(10.1)$ & $57(72.2)$ & $0(0.0)$ & $4(5.1)$ & $2.0(1.0,2.0)$ \\
\hline
\end{tabular}

Abbreviation: IQR, interquartile range.

${ }^{a}$ Category, eg, gold, silver, bronze donation.

of company donors on their website home page and 40 used the pathway starting with "About us" or the equivalent. But even within this latter group there was variability; usually the names were under a heading such as "Sponsors" or "Partners" but sometimes they were only in the annual reports. The pathways in other groups were less obvious, for instance Muscular Dystrophy Canada's list of donors was in: Services \& support: Research: Research new: Key topics in Spinal Muscular Atrophy research discussed at first ever Muscular Dystrophy Canada SMA Research Summit; for Rethink Breast Cancer the list was in: Support our movement: Partner with us (Table 2).

Congruence Between Companies Reporting Donations and Patient Groups Acknowledging Receipt of Donations

Congruence between companies reporting donations and patient groups acknowledging receipt of these donations might be more likely for large donations. Table 3 examines donations ( $\geq \$ 50000)$ to test this hypothesis. In a few cases the difference in dates between when the donation was made and received probably meant that it was not the same donation, but in general it was not possible to establish a correlation because even when patient groups reported receiving a donation from the company they often did not give the amount of the donation or the year when it was received.

Congruence Between Patient Groups Reporting Receipt of Donations and Companies Acknowledging Making Donations

Table 4 is the reciprocal of Table 3 and shows that when patient groups list donations of $\$ 50000$ or more on their websites it is very difficult to establish congruence between donations that patient groups report receiving and companies report making because of the lack of details about the exact value of the donation and the date when it was received and made.

\section{Discussion}

Only a quarter of IMC members (11/44) actually reported making donations to patient groups on their websites and frequently only the names of the patient groups were given and the value of the donation and its purpose were omitted. However, patient groups reported receiving donations from an additional 19 IMC members. In addition, some companies made large numbers of donations that were not reported. Therefore, it appears that most companies that made donations were not abiding by the guideline laid out in the IMC Code of Ethical Practices. There were no reports on the IMC website about companies failing to comply with the guideline, so it also appears that the organization is not proactively monitoring this part of its code. $(\mathrm{Rx} \& \mathrm{D}$, the previous name of IMC, said that the provision was a guideline and not a requirement because Rx\&D "could not enforce the terms of a company's relationship with a patient organization if that group was not prepared to be fully transparent"8). Further, although IMC recommends that companies report donations, that requirement does not appear to apply to IMC itself.

Patient groups reported receiving 373 donations from IMC donors, but almost one-third (35/114) did not report receiving donations from companies that claimed that they donated to the patient groups. Patient groups also infrequently reported the year the donations were made $(26.8 \%)$ and no patient group reported the exact value of the donation, although $22.0 \%$ reported the dollar range of the donation. Only 4 groups reported the purpose of the donations.

Underreporting of donations by patient groups may be due to a number of factors; companies may channel donations to patient groups through nonprofit entities that they control or substantially fund or through umbrella organizations that are not readily identifiable with those companies. ${ }^{9}$ Groups may also be concerned that publicly identifying donors could undermine their credibility in advocating for their membership.

Reporting donations by dollar ranges masks the actual amount given and can create a false sense of transparency. For example, Bayer's choice not to indicate the amount of the donation but rather to say that donations were for greater than $\$ 5000$ tells us very little about how much Bayer actually donates to patient groups. None of the 79 patient groups that reported receiving donations also reported on the percent of their overall revenue represented by donations or gave information to make that calculation. The frequent absence of dates of donations by both companies and patient groups means that reporting is not transparent and also contributes to the difficulty in linking the donations that companies give with the donations that patient groups receive even for relatively large donations. Information of this nature is necessary in order to determine if there is an association between the level of industry funding and the positions that patient groups take when the industry interests may be affected. A recent systematic review of the literature on industry funding of patient groups identified four studies that investigated the 
Table 3. Donations $\$ 50000$ and Greater Listed on Innovative Medicines Canada Member Companies' Websites and Patient Groups' Acknowledgement of Receipt of Donations

\begin{tabular}{|c|c|c|c|c|c|}
\hline $\begin{array}{l}\text { Company Making } \\
\text { Donation }\end{array}$ & Amount & $\begin{array}{l}\text { Year Company Said } \\
\text { Donation Given }\end{array}$ & Patient Group Receiving Donation & $\begin{array}{l}\text { Patient Group Acknowledges } \\
\text { Receiving a Donation From Same } \\
\text { Company on Group's Website }\end{array}$ & $\begin{array}{l}\text { Year Patient Group } \\
\text { Said Donation } \\
\text { Received }\end{array}$ \\
\hline GlaxoSmithKline & $\$ 50000$ & 2020 & Lung Association - British Columbia & No & Not stated \\
\hline GlaxoSmithKline & $\$ 139230$ & 2020 & Lung Association - Quebec & $\begin{array}{l}\text { GlaxoSmithKline listed as "gold" } \\
\text { partner }\end{array}$ & Not stated \\
\hline GlaxoSmithKline & $\$ 67500$ & 2020 & Lung Health Foundation & $\begin{array}{l}\text { GlaxoSmithKline listed as donor of } \\
\quad \$ 100000-\$ 199999\end{array}$ & 2019-2020 \\
\hline GlaxoSmithKline & $\$ 140000$ & 2020 & Ovarian Cancer Canada & No & Not stated \\
\hline Novartis & $\$ 50000$ & 2019 & Arthritis Consumer Experts & No & Not stated \\
\hline Novartis & $\$ 102000$ & 2019 & Arthritis Society & Yes & Not stated \\
\hline Novartis & $\$ 66870.28$ & 2019 & Canadian Breast Cancer Network & Yes & Not stated \\
\hline Novartis & $\$ 94502.39$ & 2019 & Canadian Council for the Blind & Novartis listed as "gold" partner & 2021 \\
\hline Novartis & $\$ 53216.18$ & 2019 & Canadian MPN Network & No & Not stated \\
\hline Novartis & $\$ 53820$ & 2019 & $\begin{array}{l}\text { Canadian National Institute for the } \\
\text { Blind }\end{array}$ & $\begin{array}{c}\text { Novartis listed as donor of } \\
\quad \$ 25000-\$ 99999\end{array}$ & 2020-2021 \\
\hline Novartis & $\$ 95000$ & 2019 & CNETS & Yes & 2020 \\
\hline Novartis & $\$ 89046.79$ & 2019 & Foundation Fighting Blindness & Yes & Not stated \\
\hline Novartis & $\$ 60000$ & 2019 & $\begin{array}{l}\text { Leukemia \& Lymphoma Society of } \\
\text { Canada }\end{array}$ & No & Not stated \\
\hline Novartis & $\$ 50000$ & 2019 & Lymphoma Canada & Yes & Not stated \\
\hline Novartis & $\$ 50000$ & 2019 & Migraine Canada & Yes & Not stated \\
\hline Novartis & $\$ 130250$ & 2019 & MS Society of Canada & No & Not stated \\
\hline Novartis & $\$ 71125$ & 2019 & Rethink Breast Cancer & No & Not stated \\
\hline Novartis & $\$ 61790.11$ & 2019 & Save Your Skin Foundation & Yes & Not stated \\
\hline Pfizer & $\$ 100000$ & 2018 & Heart \& Stroke & $\begin{array}{l}\text { Pfizer listed as donor of } \$ 25000- \\
\qquad 49999\end{array}$ & Not stated \\
\hline Roche & $\$ 80000$ & 2019 & Canadian Breast Cancer Network & $\begin{array}{l}\text { Roche listed as donor but amount } \\
\text { not given }\end{array}$ & Not stated \\
\hline Roche & $\$ 210222$ & 2019 & Canadian Hemophilia Society & Roche listed as donor of $>\$ 10000$ & Not stated \\
\hline Roche & $\$ 71612$ & 2019 & Huntington Society of Canada & $\begin{array}{l}\text { Roche listed as donor of } \$ 100000- \\
\qquad \$ 249999\end{array}$ & 2019 \\
\hline Roche & $\$ 60000$ & 2019 & Lung Association - Quebec & No & Not stated \\
\hline Roche & $\$ 75000$ & 2019 & Lung Cancer Canada & $\begin{array}{l}\text { Roche listed as donor but amount } \\
\text { not given }\end{array}$ & 2019 \\
\hline Roche & $\$ 100000$ & 2019 & Lymphoma Canada & $\begin{array}{l}\text { Roche listed as donor but amount } \\
\text { not given }\end{array}$ & Not stated \\
\hline Roche & $\$ 126900$ & 2019 & MS Society of Canada & No & Not stated \\
\hline Roche & $\$ 60000$ & 2019 & Rethink Breast Cancer & $\begin{array}{l}\text { Roche listed as donor but amount } \\
\text { not given }\end{array}$ & Not stated \\
\hline
\end{tabular}

Abbreviations: CNETS, Canadian Neuroendocrine Tumour Society; MS, multiple sclerosis.

association between patient group funding and positions that these groups took and concluded that industry funded groups tended to have positions favourable to the sponsor. ${ }^{10}$

The results of this research are broadly in line with studies in other countries. A systematic review that included five studies examining the financial relationship between patient organizations and the health industry found that the median proportion of organizations receiving industry funding and acknowledging it was 29\%. ${ }^{11}$ Drug companies reported providing funding to 157 Italian patient groups, but only 46 of these groups named at least one pharmaceutical company as providing funds. Of those 46 , three (6.5\%) reported the amount of funding, 25 (54.4\%) the activities funded and none the proportion of income derived from drug companies. ${ }^{12}$ In Australia, $52.3 \%$ of patient groups acknowledged that they had received company donations and of that group only $52.9 \%$ of patient groups reported the use of the donations that they received, $13.2 \%$ the amount and $4.4 \%$ the proportion of their income that came from industry..$^{13}$ Only $25 \%$ of the American health advocacy organizations that received grants from Eli Lilly acknowledged Lilly's contributions on their websites. ${ }^{14}$ The percent of the membership of the Association of the British Pharmaceutical Industry that reported making donations to patient groups varied from 
Table 4. Donations $\$ 50000$ and Greater Listed on Patient Groups' Websites and Companies' Acknowledgement of Making the Donations

\begin{tabular}{|c|c|c|c|c|c|}
\hline $\begin{array}{l}\text { Patient Group Receiving } \\
\text { Donation }\end{array}$ & Amount & $\begin{array}{l}\text { Year Patient Group } \\
\text { Said Donation } \\
\text { Received }\end{array}$ & $\begin{array}{l}\text { Company Making } \\
\text { Donation }\end{array}$ & $\begin{array}{l}\text { Company Acknowledges Making a } \\
\text { Donation to Same Patient Group on } \\
\text { Company's Website }\end{array}$ & $\begin{array}{l}\text { Year Company } \\
\text { Said Donation } \\
\text { Made }\end{array}$ \\
\hline Canadian Cancer Society & $\$ 50000-\$ 99999$ & Not stated & AstraZeneca & No & Not stated \\
\hline Canadian Cancer Society & $\$>100000$ & Not stated & $\begin{array}{l}\text { Janssen (Johnson \& } \\
\text { Johnson) }\end{array}$ & No & Not stated \\
\hline CATIE & $>\$ 70000$ & Not stated & Gilead & No & Not stated \\
\hline Diabetes Canada & $\$ 150000-\$ 399999$ & Not stated & AstraZeneca & No & Not stated \\
\hline Diabetes Canada & $\$ 50000-\$ 149999$ & Not stated & Lilly & No & Not stated \\
\hline Diabetes Canada & $\$ 150000-\$ 399999$ & Not stated & Janssen & No & Not stated \\
\hline Diabetes Canada & $>\$ 400000$ & Not stated & Novo Nordisk & $\begin{array}{l}\text { Diabetes Canada listed as recipient of } \\
\text { grant, amount not given }\end{array}$ & Not stated \\
\hline Diabetes Canada & $\$ 50000-\$ 149999$ & Not stated & Sanofi & No & Not stated \\
\hline Heart \& Stroke Foundation & $\$ 50000-\$ 99999$ & Not stated & Bayer & No & 2020 \\
\hline Heart \& Stroke Foundation & $\$ 50000-\$ 99999$ & Not stated & Sanofi & No & Not stated \\
\hline $\begin{array}{l}\text { Huntington Society of } \\
\text { Canada }\end{array}$ & $\$ 100000-\$ 249999$ & 2019 & Roche & $\begin{array}{l}\text { Huntington Society listed as recipient } \\
\text { of grant of } \$ 71612\end{array}$ & 2019 \\
\hline Lung Health Foundation & $\$ 100000-\$ 199999$ & 2019-2020 & AstraZeneca & No & Not stated \\
\hline Lung Health Foundation & $\$ 100000-\$ 199999$ & $2019-2020$ & Boehringer Ingelheim & No & Not stated \\
\hline Lung Health Foundation & $\$ 50000-\$ 74999$ & 2019-2020 & Bristol Myers Squibb & No & Not stated \\
\hline Lung Health Foundation & $\$ 100000-\$ 199999$ & $2019-2020$ & GlaxoSmithKline & $\begin{array}{l}\text { Lung Health Foundation listed as } \\
\text { recipient of grant of } \$ 67500\end{array}$ & 2020 \\
\hline Lung Health Foundation & $\$ 50000-\$ 74999$ & $2019-2020$ & Merck & No & Not stated \\
\hline Lung Health Foundation & \$100 000-\$199999 & 2019-2020 & Pfizer & No & 2018 \\
\hline Lung Health Foundation & $\$ 50000-\$ 74999$ & $2019-2020$ & Sanofi & No & Not stated \\
\hline Lung Health Foundation & $\$ 100000-\$ 199999$ & 2019-2020 & Takeda & No & Not stated \\
\hline Obesity Canada & $>\$ 100000$ & 2019 & Novo Nordisk & $\begin{array}{c}\text { Obesity Canada listed as recipient of } \\
\text { grant, amount not given }\end{array}$ & Not stated \\
\hline
\end{tabular}

Note: Donations from Innovative Medicines Canada not included.

$45 \%$ to $66 \%$ depending on the year. ${ }^{15}$ In the United Kingdom, 63 companies reported payments to patient groups, but 84 companies were mentioned by recipients. Although donors listed 425 recipients, only 200 (47.1\%) reported receiving payments. The number and value of payments reported by donors were $259.8 \%$ and $163.7 \%$ greater than those reported by recipients, respectively. ${ }^{16}$

Differences in companies' disclosures about the donations that they make to patient groups may be a reflection of differences in jurisdictional requirements. The codes from the Association of the British Pharmaceutical Industry ${ }^{17}$ and the European Federation of Pharmaceutical Industries and Associations ${ }^{18}$ oblige member companies to publicly disclose a list of patient organizations to which they provide donations. Similarly, each member company in Medicines Australia must list health consumer organisations to which it provides financial support and Medicines Australia publishes the reports on its publicly available website. ${ }^{19}$ In contrast, PhRMA (Pharmaceutical Research and Manufacturers of America), the American lobby group, does not require member companies to report on which patient groups have received donations from them. ${ }^{20}$

\section{Limitations}

No attempt was made to compare the total and relative number of donations made by companies and received by patient groups and therefore no "joint" list of donations could be constructed for a number of reasons. The year when donations were made and received was not regularly reported. Therefore, the lack of congruence between reporting of donations made and received could have been because a company made a donation in 2019 but it was not reported by the patient group since the group was reporting donations for 2020. Some companies or groups may keep reports for only one year, meaning some payments made more than a year ago become "invisible," but other companies or groups may keep them for longer. Also, some companies and groups may report per calendar year; others, soon after the funded activity has started or ended. Even if donations were reported by companies and groups for the same year, the lack of detail about the size of the donations means that there is no guarantee that it was the same donation. The lack of standardization in the website location of statements about donations given and received may have resulted in some donations being missed, although an attempt was made to avoid this problem 
by using Google to search on companies' and patient groups' websites. The results of this study only apply to companies that are members of IMC and reporting of donations may be different for other companies. The 164 donations that IMC members reported making is an underestimate, due to underreporting by companies. Similarly, there was underreporting by patient groups, so the exact number of donations that they collectively received from IMC members is not known. The patient groups identified in this study is not a comprehensive list of those in Canada. For example, the paper by Lexchin ${ }^{1}$ listed an additional 45 groups not included here. Finally, the data was only extracted by a single person, possibly leading to errors in recording the information, but these errors would have only been in transcribing data since no value judgements were involved. Minor transcription errors, if they occurred, would not alter the overall findings from this research.

\section{Conclusion}

Reporting on websites about donations by both companies and patient groups in Canada is haphazard, inconsistent and incomplete at present. In order to remedy this situation, patient groups should be required to post annual reports containing specified information on each donation: the name of the company making the donation, the purpose of the donation, the exact amount of the donation and the percent of their annual income that each individual donation represents and the year of the donation. All of this information should be posted under the same heading on all patient groups' websites. Based on the experience in the United Kingdom, voluntary reporting of industry donations on the websites of charity regulators results in significant under-reporting. ${ }^{16}$ This finding argues for mandatory reporting by patient groups, possibly as a requirement for the retention of their charitable status.

IMC should change its guideline about reporting donations into a requirement of membership in the organization and proactively enforce the relevant section of its Code. In addition, it should specify the information that companies must provide, including purpose, exact amount of each individual donation and the year of the donation. IMC should also require reporting to be done in the same location on all company websites to simplify locating disclosures about donations. Access to information about donations would be greatly simplified if IMC collated all of the information from individual companies and published it annually on its own website. If companies do not make full and complete reports, IMC should impose sanctions as allowed for in its Code. Finally, IMC itself should be subject to these Code requirements.

However, even if IMC undertakes these changes, its Code will not apply to non-members, such as the 56 companies that made donations to patient groups in this study. In the United Kingdom, the majority of companies failing to disclose payments were not members of the Association of the British Pharmaceutical Industry although most had voluntarily agreed to abide by its code. ${ }^{21}$ Before the Ontario election in 2019, the government was finalizing regulations for Bill 160 which required that all drug and device manufacturers that provided a "transfer of value" to individual healthcare practitioners and healthcare organizations, including patient groups, report those transfers to a public registry. ${ }^{22}$ The legislative process stopped when the government changed post-election. The federal government should pass similar legislation to make reporting mandatory on a national basis, but until that happens the Ontario government should complete the regulations so that the provincial legislation can come into effect.

Providing more information about donations will increase the accountability of both companies and patient groups and heighten transparency about their activities.

\section{Acknowledgements}

Sharon Batt, Alice Fabbri, Adriane Fugh-Berman, Barbara Mintzes, Lisa Parker and Adrienne Shnier provided valuable comments on a draft of the manuscript.

\section{Ethical issues}

All of the data for this study was publicly available and ethics approval was not required.

\section{Competing interests}

In 2018-2021, JL received payments for writing a brief in an action for side effects of a drug for Michael F. Smith, Lawyer and a second brief on the role of promotion in generating prescriptions for Goodmans LLP and from the Canadian Institutes of Health Research for presenting at a workshop on conflict-of-interest in clinical practice guidelines. He is currently a member of research groups that are receiving money from the Canadian Institutes of Health Research and the Australian National Health and Medical Research Council. He is a member of the Foundation Board of Health Action International and the Board of Canadian Doctors for Medicare. He receives royalties from University of Toronto Press and James Lorimer \& Co. Ltd. for books he has written.

Author's contribution

$\mathrm{JL}$ is the single author of the paper.

\section{Supplementary files}

Supplementary file 1. Innovative Medicines Canada Members Not Reporting Making Any Donations to Patient Groups.

Supplementary file 2. Patient Groups Reporting Receiving Donations From Innovative Medicines Canada Member Companies.

Supplementary file 3. Patient Groups Not Reporting Receiving Any Donations From Innovative Medicines Canada Members.

\section{References}

1. Lexchin J. Association between commercial funding of Canadian patient groups and their views about funding of medicines: an observational study. PLoS One. 2019;14(2):e0212399. doi:10.1371/journal.pone.0212399

2. Kang SY, Bai G, Karas L, Anderson GF. Pharmaceutical industry support of US patient advocacy organizations: an international context. Am J Public Health. 2019;109(4):559-561. doi:10.2105/ajph.2018.304946

3. Innovative Medicines Canada. Code of Ethical Practices. Innovative Medicines Canada; 2020.

4. Patented Medicine Prices Review Board (PMPRB). Annual Report 2019. Ottawa: PMPRB; 2020.

5. Member companies. http://innovativemedicines.ca/about/membercompanies/. Accessed March 24, 2021. Published 2021.

6. National Health Council. Membership application for voluntary health agencies. https://nationalhealthcouncil.org/nhc-membership-applicationfor-voluntary-health-agencies/. Accessed August 3, 2021.Published 2021.

7. von Elm E, Altman DG, Egger M, Pocock SJ, Gøtzsche PC, Vandenbroucke JP. Strengthening the reporting of observational studies in epidemiology (STROBE) statement: guidelines for reporting observational studies. BMJ. 2007;335(7624):806-808. doi:10.1136/bmj.39335.541782.AD

8. Batt S. Health Advocacy, Inc.: How Pharmaceutical Funding Changed the Breast Cancer Movement. Vancouver: UBC Press; 2017.

9. McCoy MS, Carniol M, Chockley K, Urwin JW, Emanuel EJ, Schmidt H. 
Conflicts of interest for patient-advocacy organizations. N Engl J Med. 2017;376(9):880-885. doi:10.1056/NEJMsr1610625

10. Fabbri A, Parker L, Colombo C, et al. Industry funding of patient and health consumer organisations: systematic review with meta-analysis. BMJ. 2020;368:I6925. doi:10.1136/bmj.16925

11. Khabsa J, Semaan A, El-Harakeh A, et al. Financial relationships between patient and consumer representatives and the health industry: a systematic review. Health Expect. 2020;23(2):483-495. doi:10.1111/ hex.13013

12. Colombo C, Mosconi P, Villani W, Garattini S. Patient organizations' funding from pharmaceutical companies: is disclosure clear, complete and accessible to the public? an Italian survey. PLoS One. 2012;7(5):e34974. doi:10.1371/journal.pone.0034974

13. Lau E, Fabbri A, Mintzes B. How do health consumer organisations in Australia manage pharmaceutical industry sponsorship? a cross-sectional study. Aust Health Rev. 2019;43(4):474-480. doi:10.1071/ah17288

14. Rothman SM, Raveis VH, Friedman A, Rothman DJ. Health advocacy organizations and the pharmaceutical industry: an analysis of disclosure practices. Am J Public Health. 2011;101(4):602-609. doi:10.2105/ ajph.2010.300027

15. Ozieranski P, Rickard E, Mulinari S. Exposing drug industry funding of UK patient organisations. BMJ. 2019;365:I1806. doi:10.1136/bmj.I1806

16. Ozieranski $\mathrm{P}$, Csanádi $\mathrm{M}$, Rickard $\mathrm{E}$, Mulinari S. Under-reported relationship: a comparative study of pharmaceutical industry and patient organisation payment disclosures in the UK (2012-2016). BMJ Open. 2020;10(9):e037351. doi:10.1136/bmjopen-2020-037351

17. Association of the British Pharmaceutical Industry (ABPI), Prescription Medicines Code of Practice Authority (PMCPA). ABPI Code of Practicer for the Pharmaceutical Industry 2021. London: ABPI, PMCPA; 2021.

18. European Federation of Pharmaceutical Industries and Associations (EFPIA). EFPIA Code of Practice. Brussels: EFPIA; 2019.

19. Medicines Australia. Health consumer organisation support reports. https://www.medicinesaustralia.com.au/code-of-conduct/transparencyreporting/health-consumer-organisation-support-reports/. Accessed August 4, 2021. Published 2021.

20. PhRMA. PhRMA principles on interactions with patient organizations. https://www.phrma.org/patient-support/PhRMA-Principles-onInteractions-with-Patient-Organizations. Accessed August 13, 2021. Published 2014.

21. Rickard E, Ozieranski P, Mulinari S. Evaluating the transparency of pharmaceutical company disclosure of payments to patient organisations in the UK. Health Policy. 2019;123(12):1244-1250. doi:10.1016/j. healthpol.2019.08.007

22. An Act to Amend, Repeal and Enact Various Acts in the Interest of Strengthening Quality and Accountability for Patients. https://www.ontario. ca/laws/statute/s17025. Published December 12, 2017. 